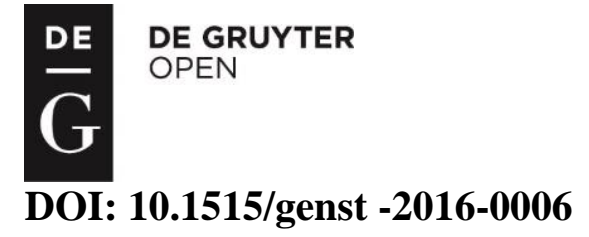

\title{
VASHTI AND SITA: THE DARING SISTERS WE COULD TRUST
}

\author{
MMAPULA D. KEBANEILWE \\ University of Botswana \\ Boitshoko Extension 10, Gaborone, Botswana \\ mdkebaneilwe92@gmail.com \\ PULANE E. MOTSWAPONG \\ University of Botswana \\ Boitshoko Extension 10, Gaborone, Botswana \\ motswaponge@mopipi.ub.bw
}

\begin{abstract}
The aim of this paper is to make a comparison between two female figures from two different religions. Vashti is one of the unsung heroines in the Book of Esther in the Hebrew Bible, while Sita in the Book of Ramayana is a revered female figure among Hindus. The tales of these women seem to display similarities in the ideals they embody and hence we endeavour to read them together. We wish to explore the extent to which Vashti and Sita's tales of female courage and daring could inspire women today who continue to suffocate under oppressive patriarchal contexts. This is relevant to the context of Botswana, where despite global efforts to bend gender-based inequality, women continue to be victimised.
\end{abstract}

Keywords: Agni pariksha, gender-based violence Rama Sita, Vashti, Xerxes. 


\section{Introduction: Vashti and Sita}

The stories of these women can be summarised as follows:

\begin{tabular}{|c|c|}
\hline $\begin{array}{l}\text { Vashti } \\
\text { At the height of banqueting, } \\
\text { an inebriated king summons } \\
\text { Queen Vashti to parade herself } \\
\text { like a beauty pageant } \\
\text { contestant before a roomful of } \\
\text { drunken dignitaries as a fitting } \\
\text { last course - a delicious feast } \\
\text { for male eyes, for she is lovely } \\
\text { to look at (Esther } 1: 11 \text { ). } \\
\text { Instead of passively doing } \\
\text { what she is told, Vashti } \\
\text { refuses. Following the counsel } \\
\text { of his advisers, Xerxes rashly } \\
\text { banishes her from his presence } \\
\text { forever and orders that every } \\
\text { man should be ruler over his } \\
\text { household. (James } 2005: 14 \text { ) }\end{array}$ & $\begin{array}{l}\text { Sita } \\
\text { Sita undergoes three ordeals: } \\
\text { First is the agni-parisksha or the fire ordeal in } \\
\text { which Sita, at the end of the great war between Rama } \\
\text { and the demons, has to undergo a test of chastity that } \\
\text { requires her to throw herself into a blazing fire. } \\
\text { Second, there is the abandonment of Sita, recounted } \\
\text { in the final book of the Valmiki Ramayana. Some } \\
\text { years after returning to his capital, Ayodhya, Rama } \\
\text { decides that despite her having passed the fire test with } \\
\text { flying colours, despite his personal certainty that she is } \\
\text { innocent, and despite her being in an advanced state of } \\
\text { pregnancy, Sita must be banished from the kingdom } \\
\text { because suspicions about her chastity are proliferating } \\
\text { in the countryside. Not only is she banished, she is } \\
\text { deceptively taken to the forest by Lakshmana (Rama's } \\
\text { brother/subject) and abandoned without a word of } \\
\text { farewell or explanation from her husband. } \\
\text { Third is the moment of rejection; a reprise of the } \\
\text { agni-pariskha with a variation occurs at the end of } \\
\text { Valmiki Ramayana. Rama makes a final attempt to } \\
\text { bring Sita back after she has lived for years in the } \\
\text { forest raising their sons to young manhood without } \\
\text { him. He suggests that she endure one more fire ordeal } \\
\text { before being allowed to stay with him in Ayodhya. Sita } \\
\text { rejects this offer and calls upon mother earth- bhumi to } \\
\text { open and receive her. Earth opens, Sita enters, earth }\end{array}$ \\
\hline
\end{tabular}


It is interesting to note that in the case of both Vashti and Sita it was the order of the day that a woman would simply bow to the demands of her male others without question. This is regardless of how ridiculous such demands might be or, worse still, how demeaning to the subject they could be. For example, Vashti was King Xerxes's wife, she was the Queen, and yet her fate was in the hands of not just the King but his advisers, the eunuchs, who were all males (Kebaneilwe 2011). That is, it is evident that by virtue of being female she was a powerless other. Similarly, Sita (also a queen) was expected by her husband King Rama to undergo yet another fire ordeal if he was to take her back after she had survived life in the forest to which she had been banished. It is worth noting that in the case of the first agni-pariksha Sita herself had volunteered to undergo it and hence her actions speak volumes about her courage and commitment to her relationship with her husband Rama, for she granted his wish without him explicitly stating it. Her action is not surrender to the unreasonable whims of a husband but rather a supreme act of defiance that challenges the accusations cast at her, by means of which she highlights the groundlessness of his doubts. She emerges as a woman whom even Agni (the fire god), who has the power to reduce to ashes everything he touches, dares not touch or harm. This time around, Sita, like Vashti takes the decisive step of defying the orders of her husband by refusing to undergo the ordeal one more time.

The notion of honour and shame plays a very significant role in the story of Sita, who becomes a victim of honour and shame. Motswapong asks: If Sita was so highly venerated and treasured by her husband and those around her, why was proving her chastity necessary? It is obvious that she 
had to undergo the test not so much for herself, as an individual, but primarily as a way of restoring her husband Rama's honour (2009:172).

The status of acceptance of a woman in society is largely dependent on the behaviour of females within the family, because a woman becomes dishonoured when she behaves like a man, enjoying freedom and especially sexual freedom (Pitt-Rivers 1965:45). Therefore, a man's honour is tied most closely to the reputation of women in his family, i.e. his mother, sister, wife, wives and daughters not his own. Any breach or any suspected violation of sexual codes by women is mainly viewed as a potent assault on a man's honour and family (see Schneider 1991:2; Kandiyoti 1987:322; Anderson, Siebert and Wagner 1988:169). Sita chooses to be defiant as she would rather be swallowed up by mother earth than go through the fire ordeal again. Her choice lands her in trouble with her powerful other, Rama, her husband. Sita's act of defiance reminds us of Vashti who, as her story recounts, acts to defy the status quo in order to defend her dignity as a person and a woman (Kebaneilwe 2011:381). Both Vashti and Sita act decisively to change and even re-write the narratives of their lives. In the face of dangerous patriarchy both women display boldness and for this we applaud them as daring sisters. Their actions taken to free themselves from oppression are deprecated by those in power. Instead of being seen as acts of courage they are viewed as deviant behaviour that is unacceptable.

It is important to underline that while the actions of these women are praiseworthy, their clash with power came at great cost. They both suffer total banishment. In Vashti's case, we never get to hear about her again; even the text becomes silent (Kebaneilwe 2011:378). As for Sita, she suffers total banishment through death as she commands the earth to break open and disappears forever. It is worth noting that Sita's appeal to Mother Earth 
to reclaim her is not the helpless reaction of an offended woman. It is a spirited, self-effacing statement of protest, when things have gone beyond what can be endured. For those of us living in this oppressive patriarchal context of Botswana, Sita's message is extremely significant. We may not necessarily ask the earth to crack open and swallow us up as Sita did, but we find ways and strength within ourselves to resist oppression based on our gender in order to change the course of our lives. Often it is easy for oppressed women to accept their predicament and take it as a norm and hence perpetuate gender-based oppression. Kebaneilwe (2011:378) sums up this stance as she narrates the story of her life in the following:

To some extent I condoned, perpetuated and upheld the same oppressive patriarch mores by trying the best I could to keep my subordinate position that however was uncomfortable and detrimental. That is, the overall cultural context and socialization overshadowed my other socialization derived from my education and my mother's private teaching at home. I knew that it was wrong and unjust for me to be victimized like that but it was hard to act defiantly; I did not want to become a deviant for fear of shame for myself and my family. Culturally I had no right to say 'no' to my husband's rule, including, among others things, no say in matters of sexuality or sex (Gichaara 2008:189). Consequently I had to endure 'marital rape' to the point that it did not matter anymore. I could never talk to anyone about these things because as a married Motswana woman you have been bought for a price, the dowry, by your husband and his family, rendering you powerless even over your own body.

Both Vashti and Sita take defiant action against what they see as violence to their integrity as women. It is noteworthy that these female figures have left behind a true legacy that could be relevant to women in oppressive patriarchal societies such as Botswana. These are stories of 
female power that could turn the tables and expose the clumsy humour of those in "power" - the male others.

\section{Many faces of gender-based oppression and abuse of women}

\section{in Botswana}

We wish to draw attention to some of the many forms of oppression and abuse that women continue to experience daily in Botswana. These include, among others, the imbalances that women encounter in relation to issues of marriage, childbearing and rearing, HIV and AIDS. Incidents of GBV in intimate relationships are closely linked to the economic dependence of women on men (Sejabosigo 2013:1). According to a study published by Gender Links for Equality and Justice and the Women's Affairs Department, over two-thirds of women in Botswana have experienced some form of gender violence in their lifetime. Gender-based violence is a huge challenge as shown by the 2010 statistics below:

8 cases of incest

518 cases of defilement of girls under the age of 16

1,865 cases of rape

1, 166 threats to kill (Murphy 2012:4)

Furthermore, women who experience GBV are also 50\% more likely to be infected with HIV than women in non-violent relationships. According to a UN report, $53 \%$ of women in Botswana have had unprotected sex because their partners refused to use condoms. This makes women more vulnerable to HIV and is clearly a concern given the prevalence of HIV in this country. Some dominant behaviours in Botswana - such as verbally abusing wives, polygamy, structural exclusion of women from decision making, and treating them as children - have been referred to as 'cultural 
practices'. It is indisputable that these practices are respected and cherished because they serve as part of our identity and a symbol of unity, but culture is not and should never be immutable. For this reason, we all need to reflect and to discourage practices that put our daughters, nieces, mothers, aunts and wives at risk of abuse.

\subsection{Marriage: a safety net or a tangled twisted noose?}

As observed by Kebaneilwe, in Setswana culture, marriage is idealised and idolised. (Kebaneilwe 2011:382)Women/girls are socialised into the stereotypical roles of wife and mother so that marriage and child bearing are idolised to the extent that anything outside of such roles is granted less recognition by the traditional society (Masenya 1997:58) Boys, on the other hand, are socialised into believing that they are the superior 'others'. They are to play the role of breadwinner for their families and to be the protectors, the leaders and heads of their households (Gichaara 2008:192). Dube (2003:103) recapitulates Botswana's patriarchal status in her assertion that as a woman raising her son, the son will soon have more power than herself on the basis of his gender. That is, being a Motswana (i.e. a citizen of Botswana) woman means being a disempowered other. What happens in marriage as a result of such socialisation?

Boys and later men carry the twisted ideology that they are superior and have control over women and girls. When they enter the married state they exercise control over their wives to the extent that women become voiceless even in matters relating to their own bodies. This is specifically perpetuated by the culture in that a woman is bought for a price in the form of Bogadi or bride price, rendering her powerless even over her own body. For instance, during patlo, a ceremony where the bride-to-be is initiated into 
the married life she is about to enter, it is stated that she is to cover up her husband's ill-doings. This is emphasised as important for maintaining the marriage. As the Setswana proverb says, mosadi o bipa mpa ka mabele, meaning 'a woman should keep silent about intimate issues in her household.' Culturally women are taught to be tough and to stand up for their households and especially their marriages against all odds even if this means losing their own lives. This has translated into a silencing culture to the detriment of the woman.

In many instances women fail to disclose the ill-treatment they encounter in their homes, including domestic violence, marital rape, their husbands' infidelity etc. Eventually women and in particular married ones become more exposed to the harsh realities that stalk them, including the menace of HIV and AIDS. In the end marriage becomes a tangled, twisted noose, far from being a safety net (Oldenburg 2002). Furthermore, in marriage a woman may experience what has been termed "fertility conundrum" (Rutenberg et.al. 2003:122-133). This expresses the conflict between either using condoms or abstaining from sex and the desire to become pregnant (122-133). The argument is that although this dilemma affects women in many settings, African women are particularly vulnerable because of the cultural emphasis on fertility (Kebaneilwe 2011:382). The sad thing is that after succumbing to the demands of childbearing, many women still find themselves stuck with the burden of caring for children and worse still bringing them up single-handedly in cases of divorce. However, the issue of divorce, especially in Botswana, is a thorny one that would require an independent research project and hence we will not at this stage take it further. 


\section{What have Vashti and Sita got to do with it?}

Vashti's story is one that says to women who have suffered abuse and violence from their male others that they can change the course of their history and the direction of their lives by saying "no" to past oppressive situations. She demonstrates that even in the face of risky and deadly patriarchy women can still choose to take control of their destiny. Her ordeal puts her on bad terms with the powerful others. There is evident fear of the 'powerless woman' by the 'powerful men' resulting from her refusal to comply with their rule. This is ironical. The humour of it lies in the fear that lurks beneath the perception by these powerful men (the king and his courtiers) that the incident will become a potential model of resistance for all (women) wives (Niditch 1995). That is, women's acts of independence through which they could decide what would happen to them poses a threat to the rule of men according to this story. This must be stopped immediately.

In the same way Sita articulates devotion and suffering. She represents compassion and grace, suffers greatly but preserves herself with heroism, love and devotion. She is the "ideal wife" according to the patriarchal context of her story. She shows her healthy sense of her own worth even at a moment of such crushing injury. She boldly reminds her husband that she is the daughter of the earth. However, her husband has failed to appreciate fully the nobility of her conduct. She tells him: "You have no reverence for the joining of our hands in my girlhood and my affectionate nature. All these you have cast away." She passionately rebukes his cruelty and gives a rational analysis of where moral responsibility lies in cases of violence against women. She does not mince her words; she says: 
...Why do you talk to me like that, Oh hero, like a common man talking to an ordinary woman? .... You, lion among men, by giving way to wrath and passing premature judgment on a woman, have acted like a worthless man (Valmiki Ramayana 1959:335-336).

Her refusal to perform a second agni-pariksha and her consequent reversion to mother earth is not merely an act of self-annihilation. It is a momentous and dignified rejection of Rama as a husband. Just as in Vashti's case, she refuses; her actions show that she no longer sees herself as the property of a man. These two women's stories tell women today that they too can make a choice to say no to oppressive situations at any time. The two women's actions serve to reveal not only humour in relation to those in power/control but the dangers that accompany their fear of those under their control. Their refusal to bow to male rule constitutes a serious challenge to a patriarchal system because it unmasks its weakness.

Rama may indeed have deselected her as his queen in deference to social opinion, but it is Sita who rejects him in a personal sense as a husband. Likewise, Vashti demonstrates her husband's conspicuous failure to control his own house. Vashti's and Sita's actions are viewed by the men in these stories as representing not only domestic and social but even cosmic disorder. In Vashti's case her insubordination provokes a state crisis (Est. 1:18-22). As a result there is an imperial edict deposing Vashti and ordering every man to be master in his own house.

By these acts both women emerge supremely triumphant. If the defining scale for quantifying greatness is the amount of suffering one has undergone, it is undoubtedly Vashti and Sita who emerge clearly as winners. It is their boldness that turns out to be their ultimate emotional strength. 


\section{Conclusions}

It may safely be concluded that Vashti and Sita present us with a paradigm shift regarding the treatment of women. It is a call for a shifting of gears from patriarchy with its associated stereotyping and marginalisation of women to a more open-minded order that appreciates women in their own right as persons. Their representations as autonomous women who act beyond the boundaries of patriarchy in order to defend their own integrity show us that they have a clearly defined sense of self. Vashti and Sita's stories are stories of power. Women who live under oppressive male rule could draw insights from the example of these two women.

\section{References}

Anderson, Roy, Siebert, Robert and Jon G. Wagner. 1998. Politics and Change in Middle East. New Jersey: Prince Hall.

Baker, Nancy V., Peter R. Gregware and Margery A. Cassidy. 1999: "Family killing fields. Honor Rationales in the Murder of Women." Violence against Women 5 (2): 164 184

Bates, Daniel G. \& Rassam, Amal. 1983. Peoples and Cultures of the Middle East. Englewood Cliffs: Prentice Hall.

Dube, Musa. 2003. HIV/AIDS and the Curriculum: Methods of Integrating HIV/ AIDS in

Theological Programmes. Geneva: WCC.

Gichaara, Jonathan. 2008. "Women, Religio-Cultural Factors." Black Theology: An International Journal, 6, (2):188-199.

Ginat, Joseph. 1979. "Illicit Sexual Relationship and Family Honour in Arab Society." Israeli Studies in Criminology 10: 179-202.

James, Carolyn C. 2005. Lost Women of the Bible: The Women we Thought we Knew. Grand Rapids: Zondervan.

Kandiyoti, Deniz A.1987. "Emancipated but Unliberated: Reflections on the Turkish Case.” Feminist Studies 13: 317-338.

Kebaneilwe, Mmapula. D. 2011 "The Vashti Paradigm: Resistance as a Strategy for Combating HIV" in Ecumenical Review 63(4): 378-383 
Lateef, S. 1992. "Wife Abuse among Indo-Fijians in D.A. Counts" in Modernisation and Social Change among Muslims in India. Brown, J.K. \& J.C. Campbell (Eds.). New Delhi. New Delhi Press.

Masenya, Madipoane. 1997. "Proverbs 31:10-31 in Southern African Context: A Reading for the Liberation of African (Northern Sotho) Women." Semeia 78: 55-68.

Motswapong, Pulane. E. 2009. Marriage Dana in Ancient and Modern India: Hindu Dowry / dahej. Germany: VDM Verlag.

Murphy, Michael. 2012. "16 Days of Activism to Stop Violence Against Women and Children", Boot Camp at Old Naledi Grounds November 26, p4. http://photos.state.gov/libraries/botswana/19452/pdfs/16\%20Days\%20of\%20Activ ism $\% 20$ to $\% 20$ Stop $\% 20$ Violence $\% 20$ Against $\% 20$ Women $\% 20$ and $\% 20$ Children $\% 2$ 0Boot\%20Camp\%20at\%20Old\%20Naledi\%20Grounds.pdf

Nfa-Abbenyi, Juliana M. 1997. Gender in African Women's Writing: Identity, Sexuality and Difference: Bloomington and Indianapolis: Indiana University Press.

Niditch, Susan.1995. "Esther: Folklore, Wisdom, Feminism and Authority" in A Feminist Companion to Esther, Judith and Susanna. Athalya Brenner (Ed.). Sheffield: Sheffield Academic Press, pp. 26-46

Oldenburg, Veena.T. 2002. Dowry Murder: The Imperial Origins of a Cultural Crime. New York: Oxford University Press.

Pitt-Rivers, Julian. (1965), "Honour and Social Status" in Honour and Shame: The Values of Mediterranean Society. Peristiany, George John. (Ed.). Chicago: Chicago Press, pp.17-97.

Rutenberg, N., Kaufman, C. E., Macintyre, K., Brown, L., \& Karim, A. 2003. "Pregnant or Positive: Adolescent Childbearing and HIV risk in KwaZulu Natal South Africa.” Reproductive Health Matters, 11(22): 122-133.

Schneider, J. L. 1971. "Of Vigilance and Virgins: Honor, Shame and Access to Resources in Mediterranean Societies.” Ethnology 10 (1): 1-24.

Sejabosigo, Josh. 2013. “Gender Benchmarking Mission, Botswana Daily News.” May 15.

[Online]. Available: http://www.dailynews.gov.bw/news-details.php?nid=2781. [Accessed 2015, July16].

Shastri, Haraprasad P. 1959. (Translated). Valmiki Ramayana. Vol 3. London: Shanti Sada. 